remark to me: "This is the way to deal with gas theories !" "

It is not perhaps fair to examine this passage too closely, as a certain amount of poetic license must be forgiven-but Maxwell did not write, "Let $n$ be 5 "; he wrote, "It will be shown that we have reasons from experiment to believe that $n=5$." Sixteen words instead of four ; but scientific accuracy has no chance when rhetorical effect is in danger, as the late Lord
Rayleigh remarked to me when I criticised a statement of a distinguished relative of his.

Shortly after his final return to Vienna, Boltzmann committed suicide. With him passed away a man of great intellectual power and a fascinating personality. His predilection for Schiller's poetry indicates a strain of morbid sentimentality, and if his humour was somewhat primitive and his technique crude, he paid dearly for his disappointments in life.

\title{
The Talking Film.
}

By Dr. E. E. Fournier D'Albe.

THE demonstration of the De Forest phonofilm at 1 the Royal Society of Arts on November 26, I924, and its recent exhibition at the Royal College of Science during the Physical and Optical Societies' Exhibition, showed that the old problem of producing a motion picture endowed with its original sound effects has been brought within hail of a perfect solution.

As Mr. C. F. Elwell remarked in the course of the demonstrations, the De Forest phonofilm was preceded by many partial solutions of the same problem.

The first "talking picture" was known as the "cameraphone"-the method employed being to make the motion picture while a stock wax cylinder type of record was played. The actors sang, or pretended to sing, and the camera photographed the lip motion. The novelty of this method made it popular for a time.

The "kinetophone" of Thomas A. Edison was the next step in advance. Better results were obtained for the reason that the phonograph record was made simultaneously with the making of the motion picture negative. The synchronisation of the sounds with the lip motion was good, but the reproduction of this synchronisation was difficult, as so much depended upon the skill of the operator, who generally had another man to start the phonograph record. If mechanical or electrical means were supplied it was difficult to keep the phonograph record and the film exactly in step. If a portion of the film became mutilated the difficulties became greater. Notwithstanding these objections the "kinetophone" enjoyed quite a large measure of popularity. But this popularity waned, and finally no more was heard of this method.

It became evident that no solution would be practically workable until a perfect synchronism between sound and movement could be automatically established. It was, therefore, necessary to look for other methods of reproducing sound. Among these the most promising was Ernst Ruhmer's "photographophone" of 1907 , in which a "speaking arc" projected light through a slit on to a moving photographic film. The audio-frequency fluctuations of the arc were thus recorded as a series of lines stretching across the film in a direction normal to its displacement, and Ruhmer succeeded in reproducing the original sound by transmitting a beam of light through this record to a selenium cell.

It was a modification of this method which Dr. Lee de Forest used for his talking motion picture. In common with Berglund and other experimenters, he confined the photographophone record to a narrow portion of the standard one-inch film as used in cinema theatres. But his method of producing the record has many original features. He uses a double-button ("push-pull") microphone with a duralumin diaphragm between the two buttons. Such a microphone is capable of carrying 20 milliamperes. It is placed

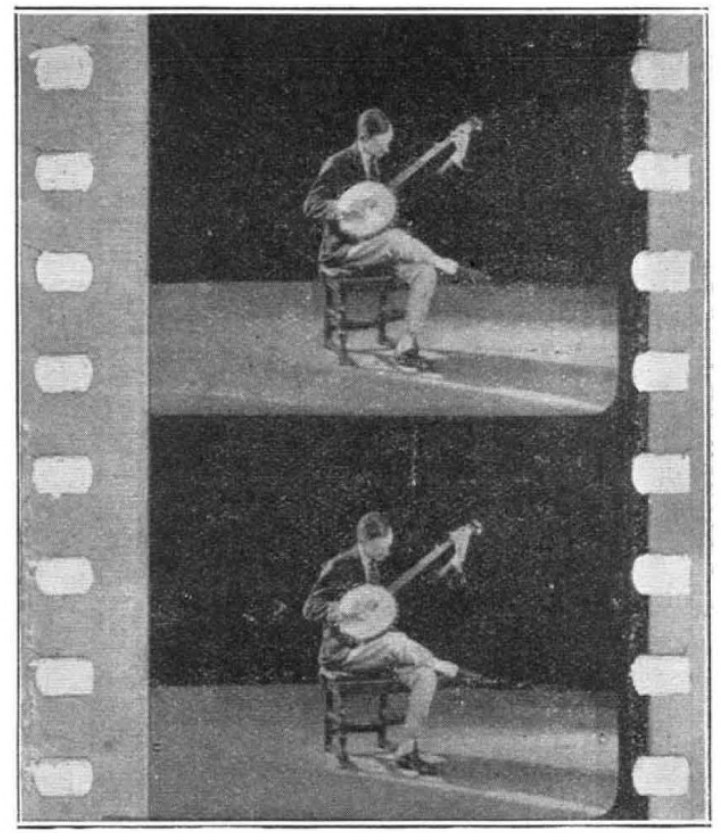

FIG. x.-Enlarged photo of piece of film showing a banjoist periorming. The cloudy strip at the left of the photograph is the music record.

about 5 feet from the speaker, and responds to all frequencies from 30 to 7000 per second.

An even better device is a condenser microphone with a capacity of 4 milli-microfarads, which is found capable of a range of 25 to 8000 vibrations per second.

The distortionless amplification of the electrical pulses yielded by the microphone is nowadays a comparatively easy matter, thanks largely to Dr. Lee de Forest's own previous inventions.

The next stage is the conversion of the electric pulses into fluctuations of actinic light. This conversion is neatly accomplished by means of a vacuum tube in which an electrode covered with barium dioxide discharges a current of some 5 milliamperes under a pressure of ${ }^{5} 5$ volts through helium at $100 \mathrm{~mm}$. pressure. This vacuum tube is called a "photion." It responds instantaneously to the variations of the 
amplified microphone current, and as its glow is of a highly actinic wave-length it produces a well-marked effect upon the film, upon which it shines through a fine slit.

It remains to reconvert the photographic record into sound. For this purpose Dr. de Forest prefers to use photo-electric cells instead of selenium, mainly on account of their more constant zero, though it is difficult to see why that should be of any consequence in the case of intermittent light. Of the various forms of photo-electric cells he prefers T. W. Case's "thalofide " (thallium oxy-sulphide) cell, which has a resistance of from 5 to 500 megohms, and works best with some 140 volts on the electrodes.

The moving film passes a fine slit, $0.038 \mathrm{~mm}$. wide and $2.3 \mathrm{~mm}$. long, illuminated by a small incandescent lamp. The electric fluctuations produced in the circuit of the photo-electric cell are excessively minute on account of its high resistance, but four or five stages of amplification suffice to enable them to operate a loud-speaker, and the actual volume of sound heard at the demonstrations showed that not much difficulty need be anticipated on that score. The remaining difficulty appears to be the distortion introduced by the loud-speaker. Whether that can be entirely eliminated remains to be seen. The rapid progress made in the construction of loud-speaking telephone receivers in recent times gives room for optimism in this direction. In the banjo solo (see Fig. I) no distortion was perceptible, but President Coolidge's speech was marked by an exaggerated American accent, most of which must have been due to the manner of reproduction. This fact may obtrude itself less upon an American audience than upon Britishers, but if it were to be perpetuated, the vogue of the American film in England would be seriously jeopardised.

It has often been objected that nobody wants the talking film; that silent film acting is an art in itself ; that the film has an international appeal, which would be lost by introducing speech and local accent; and that the art and training of even the greatest film "stars" would become useless if the film were to throw off its mantle of silence. But the most probable issue is that the talking film will develop its own art and its own industry in its own way, and although it will no doubt evolve its own conventions and limitations, it is likely to win a permanent place among the amenities of civilisation.

\section{Obituary.}

AbBé Rousselot.

$\mathrm{I}^{\mathrm{H}} \mathrm{H}$ E Abbé Rousselot passed away on December I6 last. Born in 1846 at St. Cloud (Charente), he was ordained in 1870 and became one of the teachers in the Petit Séminaire de Richemont. Leaving his pastoral work on account of his health, he devoted himself to language studies under Brachet, Bréal, and Bailly. He became convinced that " phonetics should take as its basis not dead texts but the living and speaking man." In his peregrinations from parish to parish he became keenly observant of the fact that "sounds change with perfect regularity from one region to another"; he came to believe that "phonetics could be something more and better than a descriptive science of spoken sounds, that it ought to be geographical." Noticing the differences in pronunciation among three generations of his own family living together, he got the idea of genealogical phonetics. This thought led to the foundation of the science of experimental phonetics.

Coming to Paris in 1880 , Rousselot was initiated into questions of Romance linguistics by Gaston Paris and Michel Bréal, to the physical sciences by Branley and Becquerel, to physiology by Déjerine, and to fine instrument work by Koenig. Finding it impossible to detect the finer details of spoken sounds by the ear, he complained to Gaston Paris, who said, "Only mechanical registration will give you accurate knowledge. Attempts have been made in Marey's laboratory. Go and see !"

In 1886 , Rousselot devised an electric speech recorder with which he made investigations of his native dialect. In 1889 the first course in experimental phonetics was given at the Institut Catholique de Paris. In I89I he obtained his Doctorat ès Lettres before a committee hostile to experiments - the first doctorate in experimental phonetics. He was the inspirer of La Parole and later the founder and editor of the Revue de Phonétique (I9Ir-r9I5). His great work, "Principes de phonétique expérimentale," was finished in 1908 .

In $\mathrm{x} 897, \mathrm{G}$. Paris and Bréal succeeded in founding a laboratory of experimental phonetics at the Collège de France ; it was annexed to the chair of comparative grammar (Bréal) and Rousselot was made its director. In opening the laboratory, Prof. Bréal did not hesitate to declare that "the moment has arrived when one could no longer think of phonetics as anything else than experimental "; he proclaimed that from now onward "it would be necessary to collect facts instead of announcing a priori principles."

In this heroic age, the Abbé and his pupils worked with insatiable ardour at inventing apparatus, developing methods, and collecting facts. They had to face the opposition of the whole world of linguists, grammarians, and philologists, but with ready pens they fired their bombs of explosive facts at the army of opinion and guesswork.

Rousselot had several admirers and friends of the older generation outside France. Foremost among them was the linguist and phonetician, Viëtor of Marburg, who invited Rousselot to lecture there and insisted on introducing experimental methods in a modest way. Under his auspices a phonetic cabinet was established with Calzia, a pupil of Rousselot, as chief. The speech pathologist Gutzmann developed an extensive laboratory on Rousselot's lines in Berlin in connexion with the speech clinic. Coming into phonetics from another side, I had the privilege of spending a few weeks in Rousselot's laboratory in the early days; his spirit and his methods have been the inspiration in all I have attempted since.

Few of Rousselot's pupils have succeeded in following him. The environment has usually not been favourable, and they have seldom had the inspiration that 